\title{
Profiling Intercultural Communication as Global Competence for Indonesian University Students
}

\author{
Melati $^{1{ }^{*}}$ Nyimas Triyana Safitri ${ }^{2}$ Lilik Ulfiati ${ }^{3}$
}

\author{
1,2,3 Jambi University \\ ${ }^{*}$ Corresponding author. Email: melati@unja.ac.id
}

\begin{abstract}
The skill of Intercultural Communication is needed in today's global world. This is due to the development of digital communication and the easy movement of people across the globe that increases the chances of people to meet and interact with others who are coming from different spheres of the world. By being familiar and owning Intercultural Communication competence, one would be able to communicate and to behave appropriately based on the conversation context and can achieve the goal of the interaction effectively. In a similar vein, university students as the member of academic society are also crucial to be introduced to the concept of Intercultural Communication and the skills entailed within since they frequently interact with other students and lecturers who have a different cultural background. Thus, this paper explores the components of Intercultural Competence as part of intercultural communication of students and alumni from the Faculty of Education and Teacher Training at Universitas Jambi. The data of this research are from FGD with lecturers and from document study of Faculty curriculum regarding what contributes to graduate competencies. Data show that there are several skills in Intercultural Communication that are important to be presented and practiced to fulfill the criteria of competent Intercultural speakers such as, understanding of the cultural concept, awareness of different values and norms, and recognition of Intercultural Communication practice in a workplace context. It is also found that the need for intercultural effective components to be encouraged, for example increasing students' appreciation towards their own and others' cultural values. Finally, after the components of Intercultural Communication for university students are identified, the finding can provide information for further development such as teaching instruments and assessment methods to achieve the profile.
\end{abstract}

Keywords: Intercultural Communication, profile, skill, university students.

\section{INTRODUCTION}

In this global era, people can move easily from one place to another place for many reasons like business, health, education, and others. The need for the ability to communicate and be aware of or to adapt to cultural differences is becoming imperative. Even more, these abilities to do communicate appropriately and be aware of cross-cultural issues are part of 21st-century life skills where students need to be a success in their education, life, work, and citizenship. One challenge in communication is that when people meet their interlocutors with various backgrounds and thus require different styles in communication. Students are required to recognize and identify the factors that lead to different behavior in doing communication. Meanwhile, in terms of cross-cultural issues, students have to develop their awareness about other cultures and reflect on their own culture. Thus, by possessing these skills it is expected that the students will have the knowledge and capacity to conduct appropriate and effective conversation so that the purpose of interaction will be well achieved.

To answer the call, Universitas Jambi through the program of Merdeka Belajar-Kampus Merdeka from Indonesia Ministry of Education allows students from any study program to take units from other study programs within or outside the university that the students consider important for their knowledge improvement. Intercultural communication as a unit offered at the English education study program is becoming one of the prospective units for undergraduate students to participate in the program. The rationale is this unit allows the student to learn about cultural aspects and how they play an important role in the success of communication. 
The Intercultural Communication unit is then developed to a larger extent, which becomes the focus of this research. Previously its focus limits to foreign language scope where it mainly discusses language use in the context but is then extended to a larger perspective. It will cover the need of students who are coming from other faculties or departments. Students will be allowed to analyze intercultural communication cases that are likely to happen in their disciplines, though the linguistic approach is still maintained.

From the literature review, this skill is not privileged only for language learning purposes but also for other disciplines. In the broader context of the teaching arena, research from Kural and Bayyurt [1] in 2016 reported that $43 \%$ of Turkey students who do not complete their study in the USA are due to low academic achievement and their failure to adapt to the new environment. The researcher investigated that the lack of intercultural awareness became the source of the adjustment barrier. Therefore, the research tries to set up a preparation course on cross-cultural understanding to prepare their students to study abroad. Another interesting contribution of Intercultural Communication is the success story of a sociolinguist who was able to help a lawyer winning a murder case in the courtroom which was previously accused of an aboriginal woman to be the responsible party [2]. The aboriginal woman only defended herself from domestic violence by her husband. Then in the justice process, there was a mismatch in communication between the aboriginal woman and her lawyer. By revealing the aboriginal ways of communication, the sociolinguist suggested input for the lawyer, and finally, the aboriginal woman was proved to be innocent.

Project from European Commission in 2001-2004 is another example of Intercultural Communication in the workplace context [3]. This project aims to develop an Intercultural Competence Framework and Assessment (INCA) for managers and employees at multinational engineering companies where the employees mainly came from UK, Czech Republic, Germany, and Austria. They need for better understanding of ways of working with colleagues, suppliers, managers, etc. INCA project then developed a grid of intercultural competence framework and suggested several assessment methods that fitted the situation of multinational company workers.

The examples above can serve as a basis to argue that an Intercultural speaker is a global competence indeed. As previously stated people move to and from many parts of the globe and have interaction to deal with many purposes. The knowledge of other and home cultures, as well as the ability to settle in between two cultures, are a requirement to be a successful Intercultural speaker. To achieve the purpose, students need to be encouraged not simply to observe similarities and differences between two cultures, but they should also analyze them from a viewpoint of the others and try to establish a relationship between their own and other systems.

\section{LITERATURE REVIEW}

Intercultural Communication is defined as an exchange of meaning between cultures or interaction between people from differing cultures. The goal of Intercultural Communication is to make learners able to exchange meaning appropriately in terms of linguistics and culture with other persons who have various backgrounds [4]. In an intercultural context, one must be mindful, namely, to avoid ethnocentrism and to relate to otherness.

In the Indonesian context, English is the sole foreign language that is officially taught in schools and other educational institutions. Students will experience the language and cultural differences through this subject. Thus, this contributes to the approach of teaching Intercultural Communication at Universitas Jambi. The following will be the explanation about the rationale for choosing one particular model of the Intercultural Competence framework.

Firstly, the main theory for teaching a foreign language is Communicative Competence theory. It is about how to use language communicatively that is based on how the language is used in its original context. Communicative Competence was firstly developed by Hymes where he argues that to understand L2 acquisition, it was necessary to take into account not only how grammatical competence but also the ability to use language appropriately, thus emphasizing sociolinguistic competence among native speakers. The theorists on Communicative Competence propose the need to establish communicative interaction with highly competent speakers of the language and the learners should be taught about L2 culture to provide them with the sociocultural knowledge necessary to infer the social meanings or values of the utterances.

Then one question arises how foreign language learners can perform like native users. The learners have surely possessed a system of their native language and somehow it will impact their language production. Not to mention that the speakers of English themselves have outnumbered the native speaker [5]. Thus, concerning Intercultural Communication, this article will be based on Intercultural Communicative Competence Framework proposed by Byram [6] in 2009. Byram developed his model of Interculturality to address the issue of communicative competence theory. In line with this paper, the development focus of the Intercultural Communication unit is still in recognition of the status of English in Indonesia, but at the same time can be applied to students from other disciplines. Byram [6] introduced intercultural communicative competence conception. The concept denotes "the ability of second-language 
speakers to mediate/ or interpret the values, beliefs, and behaviors (the 'cultures') of themselves and others and to stand on the bridge' or indeed 'be the bridge' between people of different languages and cultures". The following is the framework of Intercultural Communication by Byram [6]:

a. Attitudes: curiosity and openness, readiness to suspend disbelief about other cultures, and belief about one's own

b. Knowledge of social groups and their products and practices in one's own and in one's interlocutor's country, and of general processes of societal and individual interaction

c. Ability to interpret document or event from another culture, to explain it, and relate it to documents from one's own

d. Ability to acquire new knowledge of a culture and cultural practices and the ability to operate knowledge, attitudes, and skills under the constraints of real-time communication and interaction

e. Ability to evaluate critically and based on explicit criteria perspectives, practices, and products in one's own and other cultures and countries

\section{METHOD}

The research is conducted with qualitative nature, and it is intended to explore a phenomenon that exists in society (Cresswell, 2019)[8]. Concerning this research, the purpose is to gather relevant information for the sake of Intercultural Competence mapping for Universitas Jambi students. As stated earlier, competence is needed for students who want to succeed in 21 st-century life. Focus Group Discussion was employed to gather data from two groups of lecturers and there are two sets of questions addressed for each group. The first group was lecturers from English Study Program and the second group was lecturers from several disciplines such as biology, engineering, animal husbandry, civic education, physics, and Arabic language (later will be called as nonEnglish background). The English lecturer group was asked in terms of the development of the Intercultural Communication unit, namely the unit's description, and objectives, the students' competence after completing the unit, topics, classroom activities, and assessment technique. Meanwhile, for the second group, the questions mainly addressed individuals' experience in Intercultural Communication, what values that they can learn, the position of Intercultural Communication in their graduate profile, and what particular skills can be learned by students. Thus, there are two sets of responses gained from the groups.

Data were analyzed inductively, following the characteristics of qualitative inquiry (Creswell, 2019). It was done firstly by specific themes (the coding) and ended in general themes (skills mapping). As for this study, after data from FGD were transcribed, the next step was to do the coding. Themes for coding come from the heading of FGD questions so that it would be more practical.

\section{DISCUSSION}

\subsection{Data from participants with an English background}

From discussion with English lecturers, firstly there is an agreement that Intercultural Communication focuses on the importance of cultural knowledge in foreign language teaching and learning. Students can analyze the culture of the target language and home culture because familiarizing the differences and similarities between the two cultures will encourage learners' awareness in understanding the influence of culture on language learning. As widely known that it is not only the language that is different but the way to use is also different. Next, by understanding the concept of culture and language, students will be more aware of their language behavior, put more attention on the sociopragmatics aspect of language, reduce misunderstanding and misbehaving, and at the end can do effective communication. Thus, concerning this, materials explaining the definition of culture intercultural, intercultural communication will be given to students as a starting point to go further on intercultural communication issues

Analysis of speech act realization is also a topic that is recommended by English lecturers. The purpose is both for variation analysis and the application of the politeness concept. Some speech acts are frequently becoming the focus of learning English as a second language, such as apology, suggestion, compliment, and request. Students can recognize the directness level of those speech act when they are used in the context, and at the same time can analyze them in terms of politeness issue. Discourse completion tasks and role play would be the best way to know students' knowledge when performing the speech acts. The effective skill trained in this discussion is on raising students' awareness and then put their respect on the different realization of speech act among cultures. As stated in the Intercultural competence framework, affective skill is one of the goals in intercultural communication.

Based on FGD with English lecturers and also the review of related studies, other topics that need to be addressed are about clarification of values of national culture, how individual characters have a role in the success of intercultural communication, and analysis of English varieties that exist in the world. These discussions will have a more effective impact on learners besides their knowledge value. Analyzing the values of national cultures will have the effect of reducing 
stereotype that is likely to happen when talking about cultures. Then, knowing English varieties will increase students' tolerance of ambiguity since, in the use of English as a lingua franca, the users of English may come from different nations. It will contribute to different accents and dialects that students need to develop strategies to deal with those to understand the interlocutor well.

There are several ideas related to classroom interaction, topics, and assessment methods for Intercultural Communication. In the class, students can do role-playing, completing discourse tasks, discussing particular topics with classmates, writing a research project on cross-cultural data, and others. Some of the classroom interactions can be done both in an online forum such as collecting information about a country's culture by using internet-based or others can be done in the usual classroom, like doing library research. These activities might also contribute to the portfolio assessment that can be done at the end of the learning process. Students can reflect on their learning journey of intercultural communication and write a summary about it.

\subsection{Data from participants with non-English background}

Meanwhile, data from lecturers from study programs besides English Education show that the participants have a lot of experiences when they are in multicultural situations, both professional and private. One lecturer said that when she studied in Germany, she had experience with respecting other's privacy. In detail, her friend who was under the same supervisor seemed to have difficulty. Even though she is not sure, she decided not to ask anything because her friend was not looked in a good situation. She waited until her friend tell her what truly happens. At the end of the story, the participant emphasized that this attitude of respecting others is not only for the situation when we are abroad, but actually can be applied in our daily interaction in our home country. She further argues that some good traits are more practiced when she was abroad. It is something like she more reflected the good values of her home cultures when she interacted with others in a foreign country. Another participant gave his similar opinion. He focuses on exploring our home cultural values so that students can be prouder of their country. He said that Indonesia is a remarkably diverse country, that has many cultures to be explored. He is very much sure that the students are not too familiar with their own culture. He asked for the development of the Intercultural Communication unit to lay its focus on appreciating more on Indonesia's cultural norms and values. If put back to the basic idea that there is no culture overcome others, the participant maintains to actively choose and filter the value from the other culture to be more applicable in home culture.

Another focus from the participants is on ways of addressing. This issue is quite complicated for them because the way of addressing is different from the one that they usually have in-home cultures. The lecturer who studied in Germany said that the way of addressing her supervisor can be moved from honorific addressing to intimate addressing. She suggested that though the status of the supervisor was still superior to her, she can address the supervisor with more personal addressing because of the frequent interaction they had. Another participant witnessed that in Japan, there is a complex system of addressing, from personal address, second-person address, and third-person address. She recommends careful preparation before we decide to do an academic occasion there. In short, both participants suggest the knowledge of this addressing system. The mistake of addressing can lead to an awkward situation especially to the speaker we address to.

\subsection{Skills mapping}

The following is the mapping of Intercultural Communication competence, following the data and some related theories

Table 1. Summary of topics, learning outcomes, and skills of Intercultural Communication for Universitas Jambi students

\begin{tabular}{|c|l|l|}
\hline \multicolumn{1}{|c|}{ Topics } & \multicolumn{1}{c|}{ Learning Outcomes } & Skills (affective, knowledge) \\
\hline $\begin{array}{l}\text { Intercultural Communication; an } \\
\text { overview } \\
\text { a. Culture definition } \\
\text { b. Intercultural } \\
\text { Communication }\end{array}$ & $\begin{array}{l}\text { Students can draw conception } \\
\text { about culture and how it affects } \\
\text { humans' attitude and behavior }\end{array}$ & $\begin{array}{l}\text { Affective: recognize and appreciate } \\
\text { cultures that exist in one own life. }\end{array}$ \\
$\begin{array}{l}\text { Knowledge: obtain knowledge } \\
\text { about the components of } \\
\text { Intercultural Communication. }\end{array}$ \\
the workplace
\end{tabular}




\begin{tabular}{|c|c|c|}
\hline & & $\begin{array}{l}\text { Knowledge: get an update about the } \\
\text { Intercultural Communication issue } \\
\text { in the workplace context } \\
\text { Communication: }\end{array}$ \\
\hline Hoftsede cultural dimension & $\begin{array}{l}\text { By understanding the cultural } \\
\text { dimension, students can } \\
\text { conceptualize cultural differences } \\
\text { and similarities in a way that can } \\
\text { be applied when interacting with } \\
\text { people from a variety of cultures }\end{array}$ & $\begin{array}{l}\text { Affective: students are willing to } \\
\text { recognize the dimensions that build } \\
\text { up cultures } \\
\text { Knowledge: Students can analyze } \\
\text { the factors that influence the way } \\
\text { people think and behave }\end{array}$ \\
\hline $\begin{array}{l}\text { Building rapport in intercultural } \\
\text { communication }\end{array}$ & $\begin{array}{l}\text { Students are aware of building } \\
\text { good rapport in communication, } \\
\text { as well as the attitudes that are } \\
\text { required to build it }\end{array}$ & $\begin{array}{l}\text { Affective: Students respect their } \\
\text { interlocutor and recognize ways to } \\
\text { do an effective communication } \\
\text { Knowledge: Students are aware of } \\
\text { the role of rapport }\end{array}$ \\
\hline $\begin{array}{l}\text { Varieties of English } \\
\begin{aligned} \text { a. World Englishes } \\
\text { b. English as an } \\
\text { international language }\end{aligned}\end{array}$ & $\begin{array}{l}\text { Students become familiar with } \\
\text { different accents, dialects, and } \\
\text { registers that exist in varieties of } \\
\text { English }\end{array}$ & $\begin{array}{l}\text { Affective: Students become more } \\
\text { tolerant of differences that exist } \\
\text { within a language } \\
\text { Knowledge: Students can manage } \\
\text { the difficulties they might have } \\
\text { when dealing with varieties of } \\
\text { English. }\end{array}$ \\
\hline 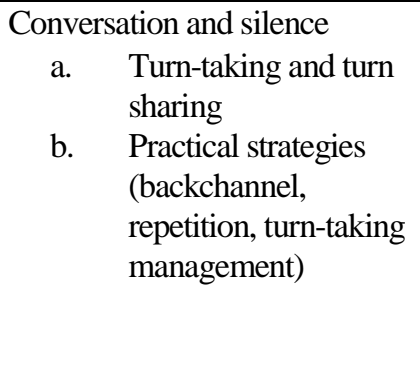 & $\begin{array}{l}\text { a. Students can recognize the } \\
\text { complexity that frequently } \\
\text { happens in communication, } \\
\text { such as anxiety and } \\
\text { uncertainty } \\
\text { b. Students understand and can } \\
\text { implement communication } \\
\text { strategies in their daily } \\
\text { interaction }\end{array}$ & $\begin{array}{l}\text { Affective: Students can identify the } \\
\text { complexity in doing conversation } \\
\text { across cultures } \\
\text { Knowledge: students can adapt to } \\
\text { communication }\end{array}$ \\
\hline $\begin{array}{l}\text { Cross-cultural speech act } \\
\text { realization } \\
\text { a. Apology } \\
\text { b. Request } \\
\text { c. compliment }\end{array}$ & $\begin{array}{l}\text { Students are aware of the } \\
\text { different realization of speech } \\
\text { acts due to cultural difference }\end{array}$ & $\begin{array}{l}\text { Affective: Students appreciate the } \\
\text { differences when realizing speech } \\
\text { acts } \\
\text { Knowledge: Students get } \\
\text { information about how speech acts } \\
\text { are realized differently in a different } \\
\text { language }\end{array}$ \\
\hline Addressing system & $\begin{array}{l}\text { Students can use an appropriate } \\
\text { addressing system }\end{array}$ & $\begin{array}{l}\text { Affective: Students show deference } \\
\text { when choosing appropriate } \\
\text { addressing } \\
\text { Knowledge: Students are aware of } \\
\text { addressing systems in different } \\
\text { cultures, including their own. }\end{array}$ \\
\hline $\begin{array}{l}\text { Toward successful intercultural } \\
\text { communication } \\
\text { a. Politeness } \\
\text { b. Accommodation } \\
\text { c. Meaning negotiation }\end{array}$ & $\begin{array}{l}\text { Students are introduced to } \\
\text { different concepts of politeness } \\
\text { (linguistic politeness) and } \\
\text { develop a strategy for successful } \\
\text { intercultural communication }\end{array}$ & $\begin{array}{l}\text { Affective: Students are willing to be } \\
\text { polite in their conversation. } \\
\text { Knowledge: Students understand the } \\
\text { concept of politeness across } \\
\text { cultures. }\end{array}$ \\
\hline
\end{tabular}




\section{CONCLUSION}

Intercultural competence facilitates native students to keep their home country's cultures, norms, values, attitudes, behaviors, and so forth to communicate effectively within their academic environments or future careers. Since they have their own cultural identities reflected in their personalities in any social context, the students will survive to maintain their daily communications in target cultures. A qualitative study was employed to answer the proposed research question in this study. Thus, Forum Group Discussion (FGD) is an instrument applied to collect the data from both English lecturer and non-English lecturer participants. This paper elaborates the profile of intercultural communication as global competence for Indonesian University Students and presents the mapping of intercultural communication competence, followed by the data and some related theories.

\section{REFERENCES}

[1] F. Kural, \& Y. Bayyurt, "The Implementation of an Intercultural Competence Syllabus to prepare study abroad students for Global Communication." Educational Studies, 2016.

[2] D. Eades, Understanding Aboriginal Silence in Legal Context. In: Helga Kotthoff and Helen Spencer-Oatey (eds.), Handbook of Intercultural Communication, Berlin: Mouton de Gruyter, 2007, pp.285-301.

[3] E. Prechtl, \& D.A. Lund, Intercultural competence and assessment: Perspectives from the INCA project. In: Helga Kotthoff and Helen SpencerOatey (eds.), Handbook of Intercultural Communication, Berlin: Mouton de Gruyter., 2007, pp.467-490.

[4] A. Mirzaei, \& F. Forouzandeh, Relationship between intercultural communicative competence and L2-learning motivation of Iranian EFL learners. Journal of Intercultural Communication Research, 2013, 42, 300e318. O

[5] R. Kusumaningputri, \& H.P. Widodo, "Promoting Indonesian University Students' Critical Intercultural Awareness in tertiary EAL classrooms: The use of digital photograph -mediated intercultural Tasks." System, 2018, 72, 49-61

[6] M. Byram, Teaching and Assessing Intercultural Communicative Competence. Clevedon. Multilingual Matters, 1997.

[7] J.W. Cresswell, Research Design: Pendekatan Metode Kualitatif, Kuantitatif, dan Campuran. Yogyakarta: Pustaka Belajar, 2019. 